\title{
Classification of Arch Height Index and Arcus Pedis to The Agility
}

\author{
Fajar Awang Irawan $^{1}$, Limpad Nurrahmad ${ }^{2}$, Dhias Fajar Widya Permana ${ }^{3}$ \\ \{fajarawang@mail.unnes.ac.id ${ }^{1}$, limpad.edu@mail.unnes.ac.id ${ }^{2}$, dhiaspermana17@ mail.unnes.ac.id ${ }^{3}$ \} \\ Universitas Negeri Semarang, Semarang, Indonesia ${ }^{1,2,3}$
}

\begin{abstract}
The purpose of this study was to classify the Arch Height Index (AHI) and Arcus Pedis to the agility. Total 48 participants with good health and has no ankle and knee injuries. This study using descriptive quantitative method with a test and measurement approach and one-shot case study design. Wet test was used to measure AHI and Arcus Pedis, while agility using Dodging Run Test. The results showed that the AHI data had an average $0.149( \pm 0.125)$, Arch Index $0.371( \pm 0.072)$, and agility test was $15,436( \pm 0.493)$. The study found that there was no significant relationship between Arch Height Index and agility. AHI and Arcus Pedis were not a determining factor in the results of agility tests. This study concludes that Arch Height Index and Arcus Pedis has no relationship with the results of the agility. Monitoring in increasing agility needs to be prioritized for performance improvement.
\end{abstract}

Keywords: arch height index, arcus pedis, agility

\section{Introduction}

Health is an absolute necessity for everyone. To get health, humans are willing to do physical activity and exercise for the achievement of life goals. In today's modern life, humans cannot be separated from sports activities either as one of a special occupation, as entertainment, recreation, livelihood, health and culture. One of the most important parts in exercising and affecting the musculoskeletal and skeletal structures in the foot is the arch foot or Arcus Pedis. Arcus Pedis in terms of human body motion can also be called foot type. The stage of curvature of everyone's feet was not the same. In general, foot type can be divided into three, there are normal arch (Normal Foot), high (Arch Foot), and low (Flat Foot). According to the research study by Lendra \& Dody [1], twenty percent of adults have flat feet and almost all newborns do not have arches like normal adults. Curved human feet are a special feature of humans that are not seen in other creatures. The main basis of the arches comes from the shape of the bones although the ligaments, tendons and muscles that form the strength and stability of the foot in supporting the establishment of the body upright. Flat foot is one of the most common conditions found in human feet. Flat foot, also called pes planus or fallen arches refers to a medical condition where the arches are flat. All parts of the foot insole attached to or almost attached to the ground, in another meaning all the part of the feet stepped on the ground. Arcus pedis in humans is formed with the intention that the feet are 
more stable when standing tread, which can distribute weight evenly to a wider area. Arcus Pedis also serves to increase speed and agility during walking and provide stabilization and flexibility [2].

Deformities of the feet can affect human health, several events that occur make the condition easily tired when walking or running, irritation of the plantaris muscles and irritation of the facia plantaris. These impacts and abnormalities can also cause tension in the muscles around the legs and physiotherapy can handle in the form of medial arch support, stretching plantaris muscles, and strengthening exercises for plantaris and leg muscles. Injuries that have a risk to the performance when exercising $[3,4,5]$ or when competing were at ankles and knees can also be caused by the form of Arcus Pedis. Arcus Pedis that does not grow normally causes impaired balance, unstable motion, deformity continues, complaints of fatigue if walking prolonged, heel shoes wear out quickly, injuries to excess surfaces, and the onset of pain. The basic thing and the possibility of being a bad impact on a career is the possibility of being unacceptable when register as a soldier or police officer or also the limitations in achievement in some sports and long-standing jobs and long-distance walking [6]. A person's ability when perform physical activity can be done through several test items contained in the components of physical conditions. Some of these items include tests of strength, speed, balance, endurance, explosive power and others. The type of the Arcus Pedis specialized in the lower extremity support the upper extremity in standing of the human body.

Based on research by Sahabuddin [7] it was found that the higher of Flat Foot grade was in the lower of dynamic balance possessed level. Darwis [8] found that agility in the Normal Foot group had better results when compared to the Flat Foot group. Hang Yu [5] in his study stated that there was no relationship between vertical jump using two feet to the height of the foot arch they have. The discovery of the vertical jump and start sprint prefix significantly influences the appearance in the human arch foot in a static or dynamic balance. Based on the results of previous research literacy conducted by the author through the method of observation and literacy studies found that college student of Sport Sciences has different foot types. The physical condition component also likely to affect the results carried out by each individual with the Arcus Pedis type when conducting a physical test, especially on the agility component. The purpose of this study was to classify the Arch Height Index using the measurement of the Arcus Pedis in knowing the agility it possesses. Recommendations and suggestions are used to improve performance in increasing agility and injury prevention.

\section{Methods}

This study using descriptive quantitative method with a test and measurement approach. One-shot case study design was used to determine the influence of Arch Height Index (AHI) and the type of Arcus Pedis possessed by each participant whose results can be seen using agility tests with Dodging Run Tests on student college of Sport Science Universitas Negeri Semarang. Total 48 participants attend in this study and the authors did not differentiate between men and women because they both had passed the tests and measurements in the class. All participants came from the various sports background such as athletics, soccer, volleyball, basketball, pencak silat, hockey, and handball. All participants were in good health and has no ankle and knee injuries that are likely to interfere the test. All participants agreed on the procedure given by signing and full fill the informed consent as proof of their 
willingness to participate in this study and accept all risks when the study was conducted. This study already qualified from the review of Health Research Ethics Committee of Universitas Negeri Semarang, Indonesia based on the Standards and Operational Guidance for Human Participants regarding WHO 2011.

To determine the research sample, a purposive sampling technique was used. This sampling technique based on criteria established by the author. These criteria include active Sports Science college student, aged between 17-24 years. Willing to be a participant by proven to full fill in informed consent, and be present to take tests and measure foot type test. After completing the identity, the next procedure was to do foot type test using a wet test based on Harris et al., [9] by attaching the soles of the feet to the ink in the mat and then placed on paper until the soles images of the feet and curves were visible. AHI data was obtained by measuring the length of the hallux valgus on the foot and arch index. The results obtained were then included in the formula as in the $\mathrm{Hu}$ [10] study. Furthermore, the agility tests were carried out and completed with data analysis using statistical analysis to find the relationship between AHI and Arcus Pedis to the agility.

\section{Results and discussions}

Associated with extraordinary events experienced globally about Covid-19, with all the capabilities carried out researchers have tried to collect primary data and relevant information to add references and research data in analyzing and classifying Arch Height Index and Arcus Pedis.

Table 1. Participant's personal data

\begin{tabular}{ccccc}
\hline $\mathbf{n = 4 8}$ & Mean & SD & Min & Max \\
\hline Height & 166.58 & 5.07 & 151 & 178 \\
Weight & 61.94 & 7.99 & 46 & 85 \\
BMI & 21.99 & 2.71 & 16 & 31.64 \\
Age & 20.58 & 0.871 & 19 & 23 \\
\hline
\end{tabular}

Table 1 explains the participants personal data that were present in the study. In this study 48 participants with an average of Height $166.58( \pm 5.07)$, Body Weight $61.94( \pm 7.99)$, Body Mass Index $21.99( \pm 2.71)$, and an average of Age $20.58( \pm 0.871)$. The number of participants who join and attended were following the procedures and sampling techniques in the study. The criteria determined are Sports Science college students who are active, aged 17 to 24 years, willing to become participants by proven to full fill informed consent, present to take agility tests and foot type Arcus Pedis measurements to completion.

Table 2. Descriptive research data

\begin{tabular}{lcccc}
\hline Variable & Mean & SD & Min & Max \\
\hline Arch Height Index (AHI) & 0.149 & 0.125 & 0.095 & 0.947 \\
Arch Index (AI) & 0.371 & 0.072 & 0.214 & 0.55 \\
Agility Test & 15.436 & 0.493 & 14.06 & 16.46 \\
\hline
\end{tabular}


The results showed that the AHI data had an average of $0.149( \pm 0.125)$, Arch Index $0.371( \pm 0.072)$, and the agility test was $15,436( \pm 0.493)$. The result showed that there was no significant relationship between Arch Height Index and agility. This also happens to Arch Index (AI) which the results of the Agility Test have no relationship to the significance value of .238> .005. Based on the statistical results above in the partial correlation test it can be seen that the Arch Height Index (AHI) and Arch Index (AI) to measure Arcus Pedis have no significant effect on the results of the Agility test. Thus, AHI and Arcus Pedis were not a determining factor in the results of agility tests held by college students of Sports Science.

Although the average of participant's Arcus Pedis has Flat Foot criteria (42 people) in this study, generally any criteria held in Arcus Pedis was a major device to support the upper extremity and also to be used as a media for moving, walking, and running. The foot part is very important of the limb and functions as a lever. Foot part also as the recipient of the deformity force in carrying out physical activity. The benefit of having the Arcus Pedis as support for bodyweight will be divided in frontally to balance the front and back and sagittal for the right and left. When standing normally, half of the weight was supported by the heel and half by the metatarsal, one-third of the body weight was supported by the metatarsal bone and the rest by the metatarsal head. The center of pressure load will also be spread evenly on the front of the sesamoid bone ostarsal ositum capitulum I and metatarsal osseum capituli IIIV and the sole of the foot in the medial processus tubercis calcanei. Whereas the center of gravity was in the middle of the sagittal plane of the body and there was no part of the body is working heavier. This will be a different story if the heels of both feet were placed on a stand so that the heel is higher like in the plantar flexion position or like wearing high heels. In this position, the center of pressure will be greater in the forelegs to support most of the bodyweight which was previously a function of part of the heel [11].

Classification of Arch Height Index (AHI) and Arcus Pedis to the agility is very important in daily activities. The problems in this study raised about AHI and Arcus Pedis on the agility of college student Sports Science. The author has the notion that the shape of the foot has an influence on the results of agility tests by college students of Sports Science. However, the results of this study were contradictory, because there was no significant relationship either between AHI and Arch Index in Arcus pedis with the agility possessed by college students of Sports Science. Normal foot shape with good agility results does not guarantee someone was able to display good performance and vice versa. The results of this study also stated that there was no relationship between AHI and Arcus Pedis on agility because the person has several possibilities such as a component of good physical condition, proper shoes with foot contours, and effective movements.
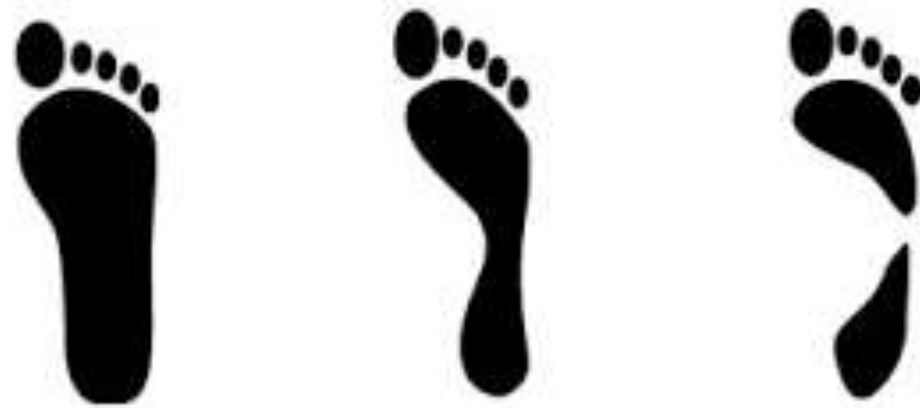

Fig. 1. Type of arcus pedis Source : Williams \& MacClay, 2000 (14) 
The type of Arcus Pedis in Figure 1 explains that the left foot is an example figure of a Flat Foot, while the middle is the Normal Foot type, and the right is the High Arch. Arcus Pedis measurement results showed that 48 participants 6 people had Normal Foot criteria, whereas for Flat Foot criteria there were 42 people, and no participants had the criteria of the High Arch in this study. The results of the agility test conducted in this study found that 7 people had Good criteria, and 41 people had Average criteria. The results of this agility test, in general, cannot be used as the main reference in determining the success of someone who has a type of the Arcus Pedis in having Good agility. Although none of the 48 participants who took part in this study had Arch Foot criteria. However, the results of this study found that 6 people have Normal Foot criteria and 42 people have Flat Foot criteria with consideration of having areas on the soles of the feet by the calculation standards in the wet test. Subsequent findings state that there was no significant relationship that states the Arch Height Index and Arch Index affect agility in college students of Sports Science. Santoso, [12] gave the advice in his study to maintain cleanliness and health for the feet because the treatment was very appropriate for someone who has Flat Foot. This study was also in accordance with the recommendations from the author through this study that participants who have Flat Foot should choose the right shoes in accordance fit with the shape of foot insole. The aim was to provide comfort to the legs when walking or running. The purpose of giving insole to the foot was to give a cushion to Hallux Valgus that it has an arch so that the foot has a reflection when making movements. Another aim was to reduce the pain or injury to the hallux that was usually unable to stand, walk, or even run for long periods, especially in people who have low AHI. Another study from Williams \& MacClay [13], stated that the measurement of Arcus Pedis can be used to determine the characteristics and Medial-longitudinal Arch which functions for the validity and reliability in the measurement foot insole.

Body Mass Index classification in this study showed that the criteria for Underweight were 2 people, 31 people have Ideal body weight, 9 people were in Overweight criteria, then 5 people have level I Obesity criteria, and 1 person in level II Obesity criteria. These results indicate that there was a good correlation even though the average participant has an Ideal body weight and logically the participant was able to practice the agility test Well even with varying BMI conditions. Need accurate measurements using a medical examination to determine the exact criteria of the Arcus Pedis and Musculoskeletal system [14],[15] on the foot insole for monitoring Arcus Pedis and performance for athletes. The limitation of this study was the author does not have data on the Arcus Pedis through the family history of each participant that can be used as the basis for the status of the Arcus Pedis for each participant has. Body fat composition data can also be a factor in determining fat in the legs which can interfere with the research data. A history of injuries to the feet, bones and joints that have not been recorded can also affect the results of the study. Further research was needed to supplement the secondary data to explain why Arch Height Index (AHI) and Arcus Pedis have no relationship to agility in college students of Sport Sciences. It is hoped that the results of this study can be a reference for further research to be able to improve the agility test and efforts to prevent injuries. 


\section{Conclusions}

This study concludes that the Arch Height Index related to the measurement of Arcus Pedis has no relationship with the results of the agility test of college students Sports Science. Not all Arcus Pedis of the participant are purely derived from the complete anatomical shape of humans. Fat deposits on the soles of the feet, the influence of hallux Valgus on human feet, Varus and Valgus on human feet can also be a factor causing changes in the contours of the soles of human feet. It is necessary to have a medical examination related to Arcus Pedis to know the complete data and check periodically to find out if there are changes or injuries experienced. Monitoring in increasing the ability of agility tests needs to be considered intensively to overcome the constraints experienced and immediately improve capabilities in the agility component owned.

\section{Acknowledgments}

This study is part of the research about the classification of Arch Height Index and Arcus Pedis to The Agility. The author would like to thank Faculty of Sports Science, Universitas Negeri Semarang for funding of this research.

\section{References}

[1] Bachtiar, F. (2012). Gambaran Arkus Pedis Pada Mahasiswa Fisioterapi. Universitas Hasanudin.

[2] Darwis, N. (2016). Perbandingan Agility Antara Normal Foot dan Flat Foot pada Atlet Unit Kegiatan Mahasiswa Basket di Kota Makasar. Universitas Hasanudin.

[3] Harris, E. J., Vanore, J. V., Thomas, J. L., Kravitz, S. R., Mendelson, S. A., Mendicino, R. W., ... Gassen, S. C. (2004). Diagnose and Treatment of Pediatric Flatfoot. The Journal of Foot \& Ankle Surgery, 43(6).

[4] Hodge, S. D. (2010). Anatomy for Litigator. The Anatomy of The Foot, 205-208.

[5] Hu, Y. (2016). The Relationship Between Foot Arch Height and two-legged Standing Vertical Jump Height in Male College-age Students.

[6] Idris, F. H. (2010). Filogeni dan Ontogeni Lengkung Kaki Manusia. Majalah Kedokteran Indonesia.

[7] Irawan, F. A., Chuang, L.-R., Peng, H.-T., \& Huang, S.-K. (2016). A Biomechanical Baseball Pitching: Is the curveball has more risk than fastball? 華人運動生物力學期刊, 13(2), 55-63. http://doi.org/10.3966/207332672016121302002

[8] Irawan, F. A., \& Long-Ren, C. (2015). Pitching Biomechanics and Injury Prevention to Improving Performance for Young Baseball Pitchers - A review. In 1st UNNES International Conference on Research Innovation \& COmmercialization for Better Life.

[9] Irawan, F. A., Putra, A. A., \& Chuang, L.-R. (2019). Physical Fitness of Adolescent Smoker. Jurnal Kesehatan Masyarakat, 14(3), 398-403.

[10] Lendra, \& Dody, M. (2007). Pengaruh Antara Kondisi kaki Datar dan Kaki Dengan Arkus Normal Terhadap Keseimbangan Statis Pada Anak Berusia 8 - 12 Tahun di Kelurahan Karangasem Surakarta. Surakarta.

[11] Neuman, D. A. (2010). Kinesiology of The Musculoskeletal System. St. Louis, Missouri: Mosby Elsevier.

[12] Sahabuddin, H. (2016). Hubungan Antara Flat Foot Dengan Keseimbangan Dinamis Pada Murid TK Sulawesi Kota Makasar. Universitas Hasanudin.

[13] Santoso, D. (2011). Perawatan Tepat Bagi Anda Yang Memiliki Telapak Kaki Datar (Flat Feet). Sport Injuries \& Rehabilitation. 
[14] Williams, D. S., \& MacClay, I. S. (2000). Measurements Used to Characterize the Foot and The Medial Longitudinal Arch: Reliability and Validity. Physical Therapy, 80(9), 864-871.

[15] Winata, H. (2015). Kaitan Pemaikaian Sepatu Hak Tinggi Dengan Lordosis Lumbal. Jurnal Kedokteran Meditek, 20(52). 